\title{
CALCULATIONS OF PHYSICAL AND CHEMICAL REACTIONS WITH DNA IN AQUEOUS SOLUTION FROH AUGER CASCADES
}

H. A. Wright*, R. N. Hamm, J. E. Turner*. R. W. Howellt, D. V. Raot, and K.S.R. Sastryt

* Heal th and Safety Research Division.

Oak Ridge National Laboratory.

Dak Ridge, Tennessee 37831-6123, USA

tUniversity of Medicine and Dentistry of New Jersey. Newark. New Jersey 07103

IUniversity of Massachusetts, Amherst. Massachusetts 01003

Running Titie: DNA Interactions from Auger Cascades

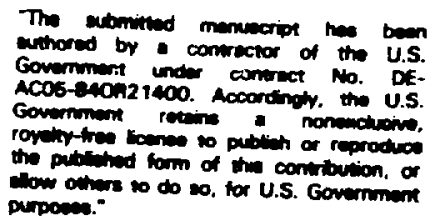




\title{
CALCULATIONS OF PHYSICAL AND CHEMICAL REACTIONS WITH
}

DNA IN AQUEOUS SOLUTION FROA AUGER CASCADES

H. A. Wright, R. N. Hamm, J. E. Turner, R. W. Howell.

D. V. Rao, and K.S.R. Sastry

\begin{abstract}
Monte Carlo calculations are performed of the physical and chemical interactions in liquid water by electrons produced during Auger cascades resulting from the decay of various radionuclides. Estimates are also made of the number of direct physical and indirect chemical interactions that would be produced on DNA located near the decay site.
\end{abstract}

\section{DISCLAIMER}

This report was prepared as an account of work sponsored by an agency of the United States Government. Neither the United States Government nor any agency thireof, nor any of their employees, makes any warranty, express or implied, or assumes any legal liability or responsibility for the accuracy, completeness, or usefulness of any information, apparatus, profuct, or process disclosed, or represents that its use would not infringe privately owned rights. Reference herein to any specific commercial product, process, or service by trade name, trademark, manufacturer, or otherwise does not necessarily constitute or imply its endorsement, recommendation, or favoring by tive United States Government or any agency thereof. The views and opinions of authors expressed herein do not neceasarily state or reflect those of the United States Government or any agency thereof. 


\section{INTRODUCTION}

The biological effects of radionuclides incorporated into mammalian cells are of considerable interest for radiation biology and radiation protection. When radionuclides decay by electron capture or internal conversion an inner atomic shell vacancy is created. The subsequent Auger transitions produce numerous low-energy electrons whose ranges are of subcellular dimensions in tissue-equivalent matter $(1,2)$. When such Auger emitters are localized on or near the DNA of cell nuclei severe biological effects are observed both in vitro and in vivo (2-4), reminiscent of alpha particles of high linear energy transfer (LET). Indeed, recent experiments with the 5.3-MeV alpha emitter Po-210, intracellularly localized, clearly showed that its lethal effects were essentially the same as those of DNA-incorporated I-125, a prolific Auger emitter $(5,6)$. The relatively high radiotoxicity of Auger emitters has been attributed to the highly localized energy density in the immediate vicinity of their decay sites (7). A more detailed understanding of the cquivalent lethality of high-LET alpha particles and DNA-bound Auger emitters may come from track-structure calculations which provide information regarding the number of direct physical interactions and subsequent indirect chemical interactions with the DNA molecule $(7,8)$. Accordingly, track-structure calculations for a variety of medical and environmental radionuclides (Fe-55, In-111. I-125, Pt-193m, Pt-195m) which emit different numbers of Auger electrons are considered in this work and compared with those for alpha particle tracks. 
MONTE CARLO SIMULATION OF AUGER CASCADES

Simulation of the nuclear and atomic events associated with the decay of several Auger-electron-emitting radionuclides was accumplished using Monte Carlo calculational techniques described in detail elsewhere (9.10). Briefly. at any stage of the radionuclide decay, the simulated decay process proceeds randomly by selecting a transition from the set of all allowed transitions for the nuclear as well as atomic configuration at that stage. As the random selections are made, data concerning the emitted radiations are recorded. This random selection process continues until the ground state of the isotope is reached.

Calculations of the energies of Auger electrons produced from a number of decays have been performed for the radionuclides $\mathrm{Pt}-195 \mathrm{~m}$. Pt-193m. I-125. In-111, and Fe-55. The Monte Carlo radiation transport code OREC (8,11-13) has been used to transport the electrons produced during the Auger cascades through liquid water surrounding the decay site and to calculate the physical and chemical interactions produced. In this code, a charged particle and all of its secondary electrons are followed, and the location and type of each inelastic energy loss event is recorded. These physical events occur within $10^{-15} \mathrm{~s}$ and produce excited or ionized water molecules and subexcitation electrons. The program then calculates the location and identity of each reactive chemical species that is produced by $10^{-12} \mathrm{~s}$. These chemical species are then followed as they undergo diffusive motion and react with each other or with solute molecules that may be present.

In order to estimate the interactions that might be produced with a DNA molecule, a very simple model has been assumed. A segment of a double-stranded DNA is represented as a right circular cylinder of radius $1 \mathrm{~nm}$ 
with "sugar" and "base" reactive sites alternating along two helical strands on the surface. Each strand makes one turn in $3.4 \mathrm{~nm}$ and has 20 reactive sites per turn. A description of this simple model has been published (8).

For the purposes of this paper two types of interactions with the DNA are considered. During the charged-particle transport the DNA cylinder is treated as though it were water, and if an inelastic energy loss event occurs within the cylinder it is considered to represent a "direct" physical event. No attempt is made to further characterize the event or its consequences. In our calculations there is no limit to the number of these direct events. An "indirect" chemical event is considered to result when a reactive chemical species interacts ith a "sugar" or "base" site on the DNA. Only one indirect event can occur with a "sugar" or "base." and hence the maximum number of indirect events is the number of sugars and bases. Although no attempt is made to identify the consequences of these direct or indirect events, it is interesting to compare the relative numbers of such events for various types of radiation.

\section{RESULTS}

Calculations have been performed of the transport of the electrons produced during Auger cascades from decay of the radionuclides Fe-55. In-111. I-125, $\mathrm{Pt}-193 \mathrm{~m}$, and $\mathrm{Pt}-195 \mathrm{~m}$. In order to get a feeling for the relative density of reactive chemical species produced during such cascades, the positions of chemical species from representative decays are plotted in Figure 1. In the four quadrants of the figure the dots represent the initial positions of the reactive chemical species $\mathrm{OH}, \mathrm{H}_{3} \mathrm{O}^{+}, \mathrm{H}$, and the hydrated electron $\mathrm{e}_{\text {aq }}^{-}$at $10^{-12} \mathrm{~s}$ before appreciable diffusion has occurred. In each 
case the positions of the sugar and base sites on the two strands of the DNA are also shown. The radionuclide decay site is taken to be on the surface of the cylinder, i.e. $1 \mathrm{~nm}$ from the axis. In the lower right quadrant the positions of chemical species produced by a 5.3-MeV alpha particle passing perpendicular to the DNA cylinder are shown. It should be noted that there is significant statistical variation in the Auger cascades. In each case we have taken examples of decays that have produced average numbers of chemical species.

Figure 2 shows the initial distribution of chemical species around the site of the decay of I-125. It shows the number of each of the 4 reactive species in concentric spherical shells of thickness $1 \mathrm{~nm}$ centered at the decay site. The hydrated electrons peak somewhat further from the decay site than the other species.

We consider now the number of events that would be produced on DNA as a result of the decay of an Auger emitter. Table 1 shows the number of direct physical and indirect chemical events that would be produced with a segment of DNA by the decay of various Auger emitters located on the surface at the middle of the cylinder, $1 \mathrm{~nm}$ from the cylinder axis. For comparison, similar information is shown for $5.3-\mathrm{MeV}$ alpha particies passing perpendicular to the DNA and $1 \mathrm{~nm}$ from the axis of the cylinder and also for 5.3-MeV alpha particles emitted isotropically from a point on the surface at the middle of the cylinder. The radionuclide Po-210 emits a 5.3-MeV alpha particle when it decays, and other studies $(5,6)$ have shown that biological ef fects similar to those from I-125 decay are produced (3).

Figure 3 shows the total number (direct plus indirect) of DNA interactions produced by the decay of various radionuclides as a function of the distance of the decay site from the center of the DNA. Also shown are the 
number of DNA interactions from $5.3-\mathrm{HeV}$ alpha particles passing perpendicular to the DNA cylinder at various distances from the axis and from 5.3-MeV alpha particles emitted isotropically from points the same distances firom the center of the DNA.

\section{CONCLUSIONS}

The essentially simuitaneous emission of electrons from an Auger cascade produces a very high energy density within a few nanometers of the decay site. If the Auger emitter is attached to the DNA it can produce damage to the DNA similar to that of a high-LET charged particle. Although the model for DNA used in this paper is very simplistic, it is interesting to compare the relative numbers of interactions produced by various radiations.

Experimental results discussed elsewhere in this volume $(5,6)$ indicate that the effects of I-125 decay and Po-210 decay producing 5.3-MeV alpha particles have similar biological effects. However, the calcuiations in this paper indicate that more DNA interactions are produced per decay by the I-125 than the Po-210. Thus one might expect the I-125 to produce more biological effects. However, the alpha particles have a range of $\sim 50$ micrometers in unit density matter and will pass entirely through a cell and may interact with the DNA in several places, whereas the high energy density regions from the I-125 decay are confined to only a few nanometers.

\section{ACKNOWT EDGEMENTS}

Research sponsored in jart by the Office of Health and Environmental Research, USDOE, under contract DE-ACO5-840R21400 with Martin Merietta Energy Systems, Inc., and in part by the USPHS under grant number $\mathrm{CA}-32877$. 


\section{REFERENCES}

1. Sastry, K.S.R., and Rao, D. V., Dosimetry of Low Energy Electrons. IN Physics of Nuclear Medicine: Recent Advances, D. V. Rao. R. Chandra, and M. Graham, Eds.. Medical Physics Monograph No. 10. American Institute of Physics, pp. 169-208 (1984).

2. Rao, D. V., Mylavarapu, V. B., Govelitz, G. F., Lanka, V. K., Sastry, K.S.R.. and Howell, R. W. Biological and Biophysical Dosimetry of Auger-emitters in vivo: A Review. IN Selected Topics in Physics of Radiotherapy and Imaging. U. Madhvanath. K. S. Parthasarathy, T. V. Venkateswaran. Eds. Tata McGraw-Hill, New Delhi, pp. 232-258 (1988).

3. Kassis, A. I., Howell, R. W., Sastry, K.S.R., and Adelstein, S. J., Positional Effects of Auger Decays in Manmalian Cells in Culture. IN DNA Damage by Auger Emitters, K. F. Baverstock, D. E. Charlton, Eds.. Taylor \& Francis, London, pp. 1-14 (1988).

4. Rao, D. V., Mylavarapu, V. B., Sastry, K.S.R., and Howell, R. W.. Internal Auger Entters: Effects on Spermatogenesis and Dogenesis in Hice. IN DNA Damage by Auger Emitters, K. F. Baverstock and D. E. Charlton. Eds., Taylor \& Francis, London, pp. 15-26 (1988).

5. Howel 1, R. W., Narra, V. R., Rao, D. V., and Sastry, K.S.R., Radiobiological Effects of Intracellular Polonium-210 Alpha Enissions: A Comparison with Auger-emitters. Radiat. Prot. Dosim. (in press).

6. Rao, D. V., Narra, V. R., Govelitz, G. F., Lanka, V. K., Howell, R. W., Sastry, K.S.R. . In vivo Effects of 5.3-MeV Alpha Particles from Po-210 in Mouse Testis: Compnrison with Internal Auger-emitters. Radiat. Prot. Dosim. (in press). 
7. Sastry, K.S.R., HowelI, R. W., Rao, D. V., Mylavarapu, V. B., Kassis, A. I., Adelstein, S. J., Wright, H. A., Hamm, R. N.. and Turner, J. E., Dosimetry of Auger-emitters: Physical and Phenomenological Approaches. IN DNA Damage by Auger Emftters, K. F. Baverstock, D. E. Charlton. Eds.. Taylor \& Francis, London, pp. 27-38 (1988).

8. Wright, H. A., Magee, J. L., Harm, R. N., Chatterjee, A., Turner, J. E. . and Klots, C. E.. Calculations of Physical and Chemical Reactions Produced in Irradiated Water Containing DNA. Rad. Prot. Dosim. 13, $133-136(1985)$

9. Howell, R. W., Sastry, K.S.R., Hill, H. Z., and Rao, D. V., Cis-Platinum-193n: Its Microdosimetry and Potential for Chemo-Auger Combination Therapy of Cancer. IN Proceedings of 4 th International Radiopharmaceutical Dosimetry Symposium, E. E. Watson and A. T. Schlafke-Stelson, Eds., Oak Ridge, TN, CONF-8511113, pp. 493-513 (1986).

10. Charlton, D. E., and Booz. J., A Monte Carlo Treatment of the Decay of I-125. Radiat. Res. 87, 10-23 (1981).

11. Turner, J. E., Magee, J. L., Wright, H. A., Chat terjee, A., Hamm, R. N., and Ritchie, R. H. . Physical and Chemical Development of Electron Tracks in Liquid Water, Radiat. Res. 96, 437-449 (1983).

12. Hamm, R. N., Turner, J. E., Ritchie, R. H., and Wright, H. A., Calculation of heavy Ion Tracks in Liquid Water. Radiat. Res. 104. S-20 - S-26 (1985).

13. Turner, J. E., Hamm, R. N. Wright, H. A., Ritchie, R. H., Magee, J. L., Chatterjee, A., and Bolch, Wesley E., Studies to Link the Basic Radiation Physics and Chemistry in Liquid Water, Radiat. Phys. Chem. 32. 503-510 $(1988)$. 


\section{FIGURE CAPTIONS}

Figure 1. Initial positions of reactive chemical species produced by representative examples of Auger cascades from the decay of the radionuclides $\mathrm{Fe}-55$, In-111, and I-125. Sugar and base sites on two helical strands of a segment of DNA are also shown. The decay site is on the surface at the middle of the cylindrical segment of DNA. The lower right quadrant shows the initial positions of chemical species produced by the passage of a 5.3-MeV alpha particle perpendicular to and at the middle of the DNA segment.

Figure 2. Average number of chemical species initially produced in spherical shells of thickness $1 \mathrm{~nm}$ centered at the decay site of I-125 Auger emitter.

Figure 3. Average number of DNA interactions (direct plus indirect) produced by decay of various radionuclides at different distances from the center of a cylindrical segment of DNA and also produced by $5.3-\mathrm{MeV}$ alpha particles passing perpendicular to the DNA cylinder or emitted isotropically from points at various distances from the center of the DNA cylinder. 
RUIARERS OF DIRECT PHYSICAL AND INDIRECT CIEMICAL INTERACTIONS FRODUCTD ON DNA BY AUCER EMITTERS LOCATTD ON TIE SURFACE OF THE $1 \mathrm{n}$ m RADIUS DNA CMLINDER OOMPARED WITHI TIOSE FROM 5.3-MeV ALPIIA PARTICIES PASSING $1 \mathrm{~nm}$ FROM TIE CENTER OF THE DNA CYLINDER PERPENDICULAR TO ITS AXIS AND WITH 5.3-MeV ALPII PARTICIES EMITTED ISOIROPICAIIY AT 1 na FROM TIE CENIER OF TIE DNA.

\begin{tabular}{|c|c|c|}
\hline & DIRECT & INDIRECT \\
\hline $\mathrm{Pt}-195 \mathrm{~m}$ & 36 & 56 \\
\hline Pt-193m & 35 & 52 \\
\hline $\mathrm{I}-125$ & 21 & 44 \\
\hline In-111 & 11 & 30 \\
\hline $\mathrm{Fe}-55$ & 5 & 18 \\
\hline 5.3-MeV alpha perpendicular & 4 & 29 \\
\hline 5.3-MeV alpha isotropic & 4 & 18 \\
\hline
\end{tabular}


ORNL-DWG 89-11441

${ }^{55} \mathrm{Fe}$

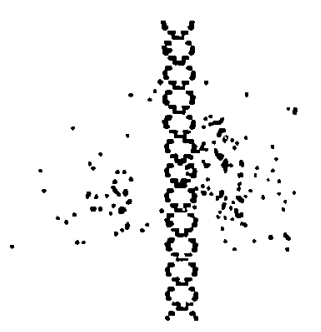

125

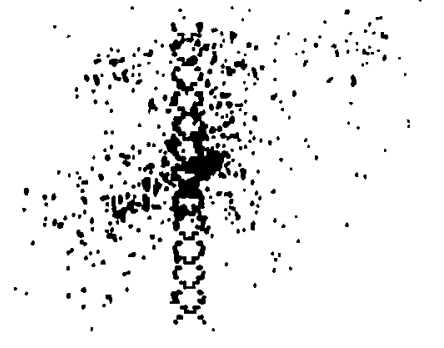

111

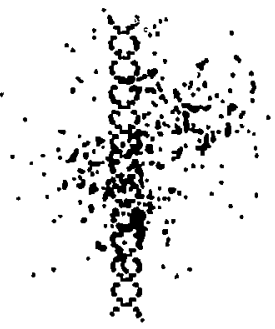

$1-1$

$10 \mathrm{~nm}$

\section{3-MeV ALPHA}

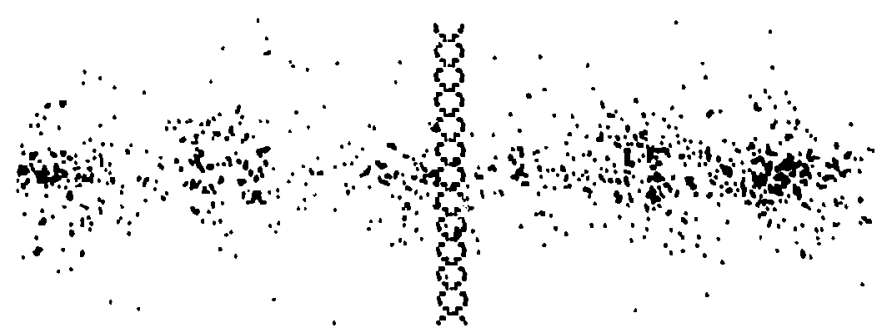


ORNL-DWG 89-10536

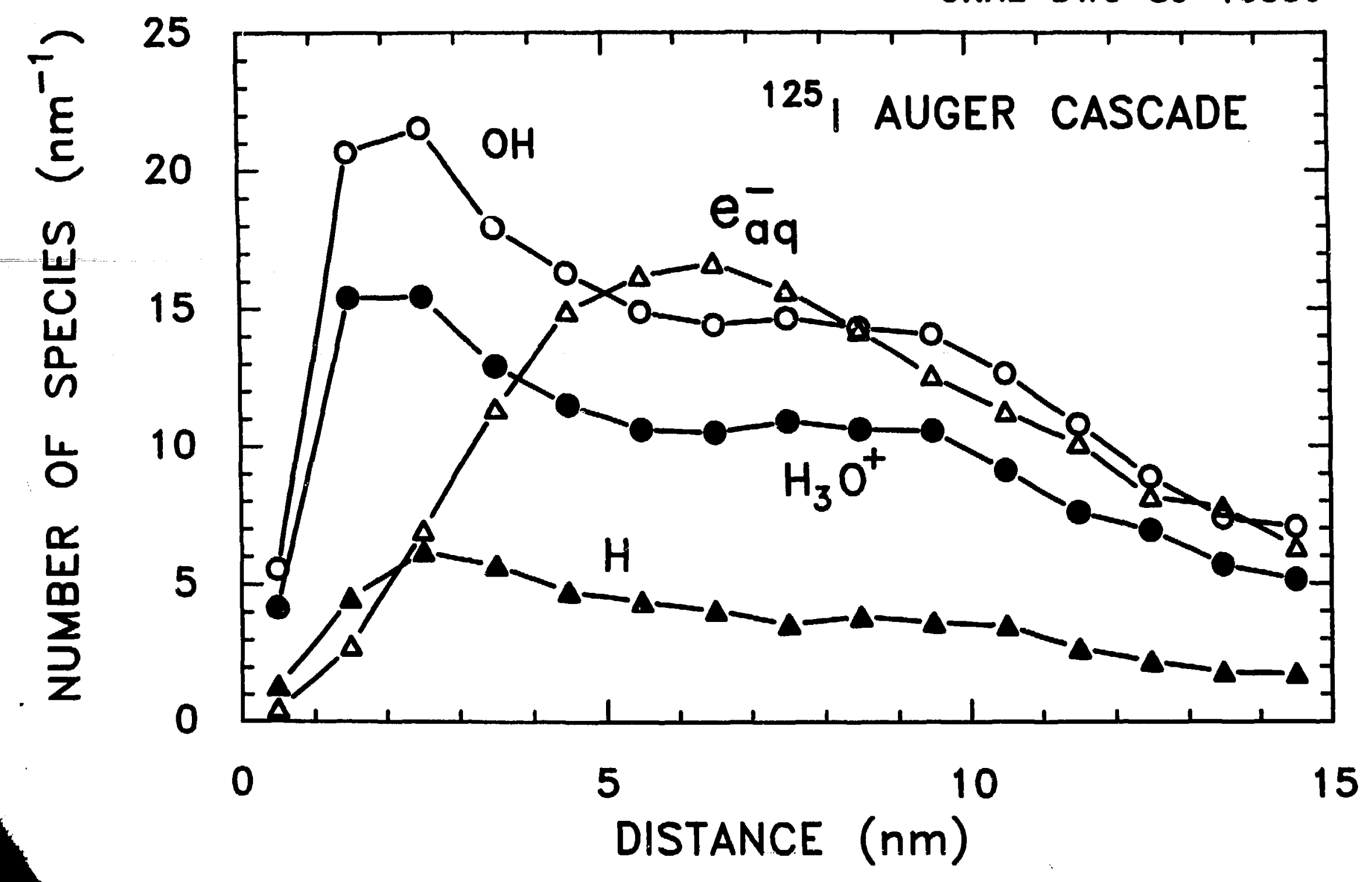


ORNL-DWG 89-10540

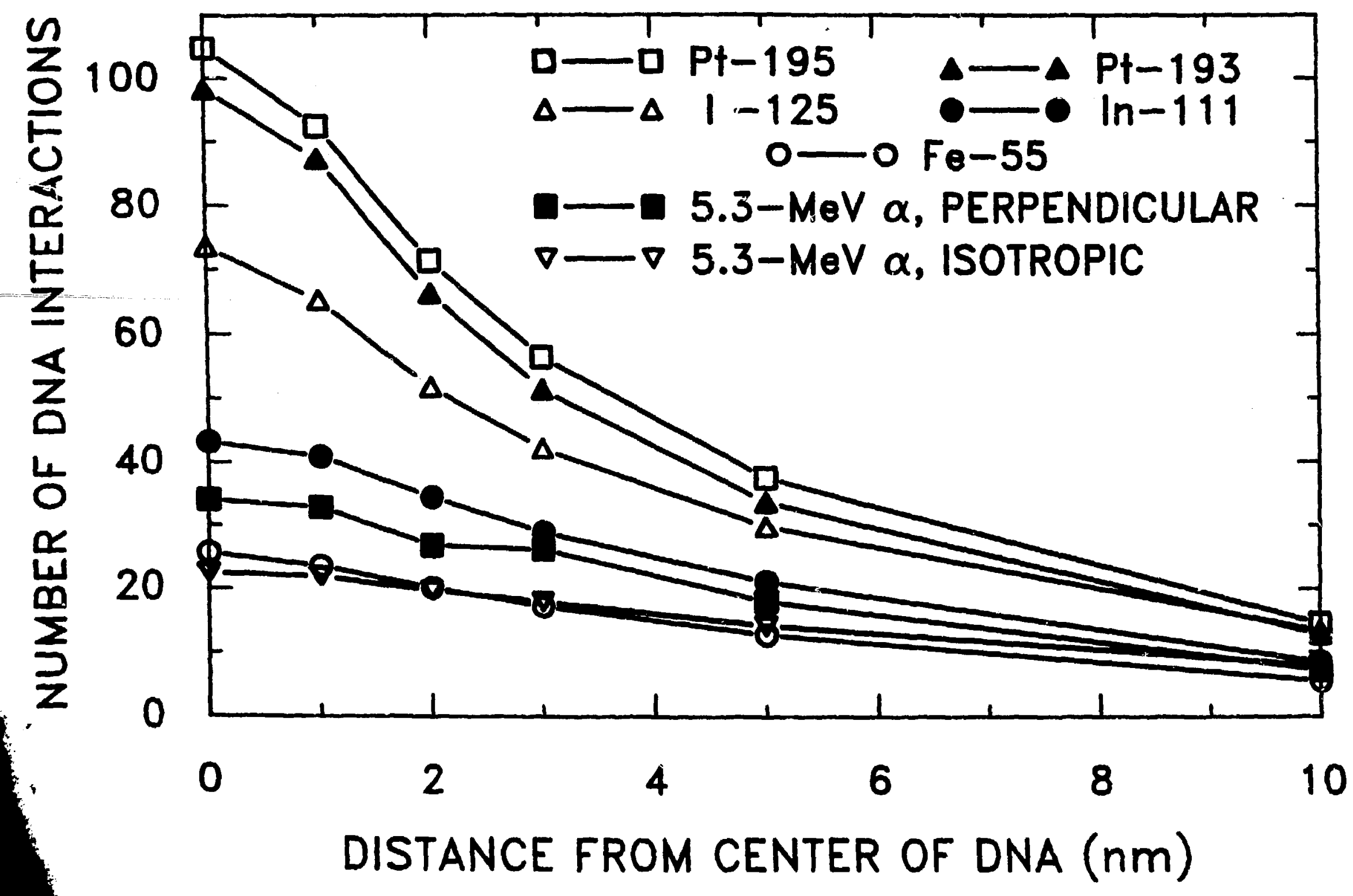

